\title{
MENAKAR KEDAULATAN NEGARA \\ DALAM PERSPEKTIF KEIMIGRASIAN
}

(Assessing State's Sovereignty from the Perspective of Immigration Affairs)

\author{
M. Alvi Syahrin \\ Politeknik Imigrasi \\ Badan Pengembangan Sumber Daya Manusia Hukum dan HAM \\ Kementerian Hukum dan Hak Asasi Manusia R.I. \\ Jl. Raya Gandul No. 4, Cinere, Depok, Jawa Barat, Telepon: (021) 7530001 \\ Email:ma.syahrin@gmail.com
}

Tulisan Diterima: 22-09-2017; Direvisi: 02-03-2018; Disetujui Diterbitkan: 06-03-2018

DOI: http://dx.doi.org/10.30641/dejure.2018.V18.43-57

\begin{abstract}
Sovereignty means that a country has full power to exercise its territorial powers within its jurisdiction. The embodiment of the state sovereignty is on the hands of, among others, the Directorate General of Immigration. However, currently the state sovereignty is in worrying conditions. This may be seed from the increased number of refugees and asylum seekers. Not to mention the exodus of foreign workers from China who are now starting to expand to the manpower sector. The problem being investigated in this paper is the prevalence of the Indonesia sovereignty from the perspective of immigration affairs. The research method used in this paper qualitative normative legal research method combined with mixed logical thinking (deductive and inductive). The result of the research finds that the issues of visa-free policies, refugees and asylum seekers affairs as well as the exodus of foreign workers from China have brought significant direct impact to the State Sovereignty of Indonesia. This must have influenced the ideological, political, economic, social, cultural, security and defence orders as well as the state sovereignty itself. This is a serious challenge Indonesia must encounter. The Directorate General of Immigration must act as the spearhead in securing the dignity of the state (bhumi pura wira wibawa).
\end{abstract}

Keywords: State Sovereignty, Immigration, Directorate General of Immigration

\begin{abstract}
ABSTRAK
Kedaulatan mengandung arti bahwa negara mempunyai hak kekuasaan penuh untuk melaksanakan hak teritorialnya dalam batas wilayah negara yang bersangkutan. Perwujudan kedaulatan negara tersebut diemban oleh Direktorat Jenderal Imigrasi. Namun, kini kedaulatan negara berada dalam situasi yang mengkhawatirkan. Hal tersebut, dapat dilihat dari semakin meningkatnya keberadaan pengungsi dan pencari suaka. Belum lagi adanya eksodus tenaga kerja asing asal Tiongkok yang kini mulai mengekspansi sektor ketenagakerjaan. Rumusan masalah yang diteliti dalam tulisan ini adalah bagaimana keberlakuan eksistensi kedaulatan negara Indonesia dalam perspektif keimigrasian. Metode penelitian yang digunakan adalah penelitian hukum normatif yang bersifat kualitatif dan logika berpikir campuran (deduktif dan induktif). Dari hasil penelitian dapat diketahui bahwa permasalahan kebijakan bebas visa kunjungan, keberadaan pengungsi dan pencari suaka, serta eksodus tenaga kerja asing Tiongkok berdampak langsung terhadap kedaulatan negara Indonesia. Hal ini tentu mempengaruhi tatanan ideologi, politik, ekonomi, sosial budaya, pertahanan dan keamanan, serta kedaulatan negara. Inilah yang menjadi tantangan serius yang harus dihadapi. Direktorat Jenderal Imigrasi harus menjadi otoritas terdepan dalam menjaga wibawa pintu gerbang negara (bhumi pura wira wibawa).
\end{abstract}

Kata Kunci: Kedaulatan Negara, Imigrasi, Direktorat Jenderal Imigrasi 


\section{PENDAHULUAN}

Berbicara tentang kedaulatan selalu identik dengan kekuasaan Negara Kesatuan Republik Indonesia (NKRI). Menurut Kamus Besar Bahasa Indonesia, kedaulatan adalah kekuasaan tertinggi atas pemerintahan Negara. Menurut Jean Bodin seorang filsuf politik yang berasal dari Perancis, ada empat sifat pokok kedaulatan yaitu: (1) Permanen, artinya kedaulatan yang tetap ada selama negara itu masih berdiri; (2) Asli, artinya kedaulatan itu tidak berasal dari kekuasaan lain yang lebih tinggi; (3) Bulat, artinya kedaulatan itu hanya satu-satunya kekuasaan yang tertinggi; (4) Tidak terbatas, artinya tidak ada yang terbatas, sebab apabila terbatas maka sifat tertinggi akan lenyap (Friedman, 2016: 412-416).

Dari keempat sifat tersebut dapat dirumuskan bahwa kedaulatan NKRI itu terdapat dalam beberapa Teori Kedaulatan, yaitu: Teori Kedaulatan Tuhan, Teori Kedaulatan Negara, Teori Kedaulatan Hukum, dan Teori Kedaulatan Rakyat. Konsekuensinya, keempat teori ini menjadi simbol bahwa kekuatan mengikat kedaulatan negara Indonesia menjadi sangat variatif ukurannya.

Indonesia menganut Teori kedaulatan Tuhan berdasarkan pada Sila Pertama Pancasila dan Alinea Ketiga Pembukaan Undang-Undang Dasar Negara Republik Indonesia Tahun 1945, serta Pasal 29 ayat (1) UUD 1945 yang berbunyi "Negara berdasarkan atas Ketuhanan yang Maha Esa”. Lalu, perwujudan Teori Kedaulatan Negara tercermin pada Alenia Keempat Pembukaan UUD Tahun 1945. Teori kedaulatan hukum juga dapat dibuktikan dengan Pasal 1 ayat (3) UUD 1945, yaitu: "Negara Indonesia adalah Negara Hukum". Sedangkan, Teori Kedaulatan Rakyat dibuktikan dengan Pasal 1 Ayat (2) UUD 1945, yaitu: "Kedaulatan berada di tangan rakyat dan dilaksanakan menurut Undang-Undang Dasar". Lalu terdapat pada Sila Keempat Pancasila, yaitu: "Kerakyatan yang dipimpin oleh hikmat kebijaksanaan dalam permusyawaratan perwakilan".

Kedaulatan NKRI sendiri berada di tangan rakyat, sehingga pemerintah harus menyadari bahwa rakyat pemegang kekuasaan tertinggi dalam menjalankan kehidupan bernegara dan menjaga kedaulatan NKRI. Pemerintah harus berhati-hati dalam mengambil sikap dan kebijakan yang bisa bertentangan dengan kehendak masyarakat banyak. Kebijakan Bebas Visa yang digulirkan oleh pemerintah, telah menimbulkan pro dan kontra di lapisan masyarakat. Belum lagi, keberadaan pengungsi dan pencari suaka yang setiap tahun semakin meningkat (Syahrin, 2015: 29-31). Kedaulatan NKRI sangat bergantung pada bagaimana kinerja Direktorat Jenderal Imigrasi sebagai pengemban tugas penjaga pintu gerbang negara. Lemahnya peran Direktorat Jenderal Imigrasi, berarti harus bersiap kehilangan kedaulatan negara.

Berdasarkan uraian di atas, maka permasalahan yang akan dibahas dalam tulisan ini adalah: Bagaimanakah keberlakukan eksistensi kedaulatan negara Indonesia dalam perspektif keimigrasian? Adapun tujuan penelitian ini adalah untuk mengetahui sejauh mana kekuatan dan keberadaan kedaulatan negara Indonesia dalam konsep keimigrasian, baik itu terkait dengan pengawasan dan penegakan hukumnya. Manfaat teoretis dari penelitian ini adalah untuk pengembangan ilmu pengetahuan khususnya hukum keimigrasian. Sedangkan manfaat praktisnya sebagai bahan pertimbangan bagi para stake holder, khususnya Direktorat Jenderal Imigrasi dalam membuat kebijakan dan peraturan di bidang keimigrasian.

\section{METODE PENELITIAN}

\section{Pendekatan}

Jenis pendekatan yang digunakan adalah penelitian hukum normatif yang bersifat kualitatif. Maksudnya adalah penelitian yang menggambarkan, menjelaskan, menganalisis, serta mengembangkan konstruksi hukum kedaulatan negara dalam perspektif imigrasi (Marzuki, 2015: 35).

\section{Metode Pengumpulan Data}

Pengumpulan bahan-bahan hukum dilakukan dengan mengidentikasi dan menginventarisasi peraturan perundang-undangan, meneliti bahan pustaka (tulisan dan hasil karya ilmiah), dan sumber-sumber bahan hukum lainnya yang ada relevansinya dengan isu hukum dalam penelitian ini.

\section{Teknik Analisa Data}

Teknik analisa isu hukum (legal issue) dalam penelitian ini menggunakan logika berpikir campuran. Maksudnya penalaran (hukum) yang 
merupakan gabungan dari pola berpikir induktif (inductive) dan deduktf (deductive) dalam persoalan hukum faktual yang konkrit. Proses yang terjadi dalam logika berpikir campuran adalah abstraksi (hukum), nilai-nilai hukum, asasasas hukum, konsep-konsep hukum, dan normanorma hukum yang dirumuskan secara umum dalam aturan-aturan hukum positif, kemudian dikonkritisasi (dijabarkan) dan diterapkan guna penyelesaian persoalan hukum konkrit yang dihadapi, begitu juga seterusnya secara bolakbalik dalam proses campuran (Ardhiswastra, 2017: 158-159).

\section{PEMBAHASAN}

\section{A. Konsep Kedaulatan Negara dalam Perspektif Keimigrasian}

\section{Hakikat Keimigrasian}

Hadirnya globalisasi telah memudahkan setiap orang untuk melakukan perjalanan dari suatu negara ke negara lain. Kebebasan pergerakan manusia untuk berpindah antar negara merupakan suatu hak dasar atau asasi manusia yang dijamin dalam konstitusi. Hak bermigrasi ini diatur dalam Pasal 28E UUD 1945 (Amandemen), yang menentukan bahwa: "Setiap warga negara bebas untuk .... memilih tempat tinggal di wilayah negara dan meninggalkannya, serta berhak kembali." (Syahrin, 2015: 45-48); (Nasution, 2016: 11)

Secara yuridis, Pasal 1 Angka (1) UndangUndang Nomor 6 Tahun 2011 tentang Keimigrasian (selanjutnya disebut UU No. 6 Tahun 2011) menegaskan sebagai berikut:"Keimigrasian adalah hal ihwal lalu lintas orang yang masuk atau keluar Wilayah Indonesia serta pengawasannya dalam rangka menjaga tegaknya kedaulatan negara". Pasal 1Angka (3) disebutkan bahwa Catur Fungsi Imigrasi, yaitu: (i) pelayanan masyarakat, (ii) penegakan hukum, (ii) keamanan negara, (iv) pembangunan kesejahteraan masyarakat, maka Imigrasi memiliki peran penting dalam menjaga kedaulatan negara.

Dalam Pasal 8 UU No. 6 Tahun 2011 dijelaskan bahwa setiap orang yang masuk atau keluar Wilayah Indonesia harus memiliki dokumen perjalanan, yaitu dokumen resmi yang dikeluarkan oleh pejabat yang berwenang dari suatu negara yang memuat identitas pemegangnya dan berlaku untuk melakukan perjalanan antar negara. Tanpa memiliki surat perjalanan (paspor) yang sah dan masih berlaku, tidak seorang pun dapat diizinkan masuk atau keluar Wilayah Indonesia.

Satu dari sekian banyak ketentuan hukum dalam UU No. 6 Tahun 2011 yang menjadi "aturan khas Imigrasi" tentu Pasal 75 Ayat (1) UU No 6 Tahun 2011. Pasal tersebut menyatakan bahwa: "Pejabat Imigrasi berwenang melakukan Tindakan Adminstratif Keimigrasian terhadap Orang Asing yang berada di Wilayah Indonesia yang melakukan kegiatan berbahaya dan patut diduga membahayakan keamanan dan ketertiban umum atau tidak menghormati atau tidak menaati peraturan perundang-undangan". Disadari atau tidak, pasal ini merupakan aturan hukum yang menjadi dasar bagi setiap Pejabat Imigrasi untuk dapat secara maksimal mengawal dan menjaga pintu gerbang negara dari setiap ancaman orang asing yang hendak masuk ke wilayah Indonesia.

Berdasarkan pasal ini, setiap Pejabat Imigrasi dapat melakukan tindakan administratif berupa pencatuman dalam daftar pencegahan atau penangkalan, pembatasan, perubahan, atau pembatalan Izin Tinggal, pengenaan biaya beban, bahkan melakukan deportasi dari wilayah Indonesia (vide Pasal 75 ayat 2 UU No. 6 Tahun 2011). Pejabat Imigrasi yang melakukan tindakan administratif dimaksud, dapat bersandar pada klausul "dugaan" semata, atau menganggap orang asing tersebut tidak memiliki manfaat (asas kemanfaatan) bagi negara Indonesia, berdasarkan asas kebijakan selektif (selective policy priniciple). Jadi dalam hal ini tidak berlaku asas praduga tidak bersalah (presumption of innocence principle), seperti yang dipahami dalam Hukum Acara Pidana. Hal ini berbeda apabila kita samakan dengan proses pro justitia (penegakan hukum) di bidang hukum pidana yang harus berdasarkan pada dua alat bukti yang sah dan keyakinan hakim (Pasal 183 KUHAP). Di sinilah letak hak ekslusif (previlege rigths) setiap Pejabat Imigrasi yang tidak dimiliki oleh penegak hukum di instansi lainnya. Pasal khas yang menjadi perwujudan kedaulatan negara.

\section{Tempat Pemeriksaan Imigrasi: Kedaulatan Negara dalam Batas Imajiner}

Berdasarkan Deklarasi Juanda, tanggal 13 Desember 1957, Indonesia dikenal sebagai negara kepulauan (archipelago state). Sebagai negara yang diapit oleh dua benua dan dua samudera, Indonesia memiliki tantangan sendiri dalam 
melakukan implementasi fungsi keimigrasian. Setidaknya ada sepuluh negara yang berbatasan langsung ataupun tidak langsung dengan Indonesia, baik itu perbatasan darat ataupun laut (Santoso, 2014: 58).

Berdasarkan data yang penulis himpun dari website imigrasi.go.id per tanggal 14 Oktober 2014, ada 203 Tempat Pemeriksaan Imigrasi (TPI) yang tersebar di seluruh penjuru Indonesia (konvensional dan tradisional), yang terdiri dari 91 pelabuhan laut, 33 bandar udara, dan 79 pos lintas batas. Keberadaan TPI sebanyak ini tentu membuat peran institusi Imigrasi menjadi sangat penting.

TPI merupakan cerminan kedaulatan negara imajiner yang ditentukan oleh Otoritas Imigrasi. Keberadaan TPI berkaitan erat dengan Area Imigrasi. Pasal 22 ayat (2) UU No. 6 Tahun 2011 menentukan bahwa Area imigrasi merupakan area terbatas yang hanya dapat dilalui oleh penumpang atau awak alat angkut yang akan keluar atau masuk Wilayah Indonesia atau pejabat dan petugas yang berwenang.

Sebagai area internasional yang ditandai oleh garis kuning (yellow line), area imigrasi memiliki kedudukan yang sama pentingnya dengan kedaulatan suatu negara(Wilner, 2015: 2-3). Walaupun hanya sebatas garis imajiner, Area Imigrasi memiliki representasi kewibawaan dari negara tersebut. Pasal 22 ayat (3) UU No. 6 Tahun 2011 menyatakan bahwa: "Kepala Kantor Imigrasi bersama-sama dengan penyelenggara bandar udara, pelabuhan laut, dan pos lintas batas menetapkan area imigrasi sebagaimana dimaksud pada Ayat (1)." Oleh karenanya, area imigrasi memiliki kedudukan hukum yang jelas dan harus dihargai.

Realitasnya, Area Imigrasi tidak sepenuhnya dapat dipahami oleh sebagian pihak sebagai kedaulatan suatu negara. Kasus ditangkapnya Susno Duaji (sebelum diundangkannya UU No. 6 Tahun 2011) oleh Provost Polri di Terminal 2 Bandar Udara Soekarno Hatta beberapa waktu lalu menjadi preseden buruk yang melecehkan wibawa Area Imigrasi (Fahroy dan Syahrin, 2016: 1632). Padahal saat itu, Susno Duaji telah melewati Tempat Pemeriksaan Imigrasi dan berada di ruang tunggu keberangkatan. selama berada di area imigrasi, Susno Duaji seharusnya mendapatkan perlindungan hukum secara internasional

\section{Kebijakan Selektif Keimigrasian}

Teori kebijakan selektif keimigrasian merupakan prinsip fundamental yang berlaku universal bagi seluruh negara di dunia. Prinsip ini merupakan perwujudan kedaulatan negara yang harus dihormati (Santoso, 2017: 37). Dalam hukum positif, kebijakan selektif keimigrasian dicantumkan dalam Pasal 75 dan Bagian Kesatu Penjelasan Undang-Undang Nomor 6 Tahun 2011 yang menjelaskan bahwa:

"Berdasarkan kebijakan selektif (selective policy) yang menjunjung tinggi nilai hak asasi manusia, diatur masuknya orang asing ke dalam wilayah Indonesia, demikian pula bagi orang asing yang memperoleh Izin Tinggai di wilayah Indonesia harus sesuai dengan maksud dan tujuannya berada di Indonesia. Berdasarkan kebijakan dimaksud serta dalam rangka melindungi kepentingan nasional, hanya orang asing yang memberikan manfaat serta tidak membahayakan keamanan dan ketertiban umum diperbolehkan masuk dan berada di wilayah Indonesia."

Berdasarkan prinsip hukum yang diatur dalam Pasal 75 dan Bagian Kesatu Penjelasan UU No. 6 Tahun 2011, kebijakan selektif ini mengharuskan bahwa:

a. hanya orang asing yang bermanfaat yang diperbolehkan masuk dan berada di wilayah Indonesia;

b. hanya orang asing yang tidak membahayakan keamanan dan ketertiban umum yang diperbolehkan masuk dan berada di wilayah Indonesia;

c. orang asing harus tunduk pada peraturan hukum di Indonesia;

d. orang asing yang masuk dan berada di wilayah Indonesia harus sesuai dengan maksud dan tujuannya.

Berdasarkan prinsip ini, maka hanya orang asing yang dapat memberikan manfaat bagi kesejahteraan rakyat, bangsa, dan negara, tidak membahayakan keamanan dan ketertiban, serta tidak bermusuhan baik terhadap rakyat yang dapat masuk dan keluar wilayah Indonesia (Indra, 2015: 2). Bahkan dalam tafsir lain, pergerakan orang asing tersebut harus dapat sesuai dengan ideologi negara dan tidak mengancam keutuhan bangsa. 
Lebih lanjut, kebijakan selektif ini dalam pelaksanaannya harus memperhatikan keseimbangan antara pendekatan keamanan (security approach) dan pendekatan kesejahteraan (prosperity approach) (Tinggartomanu, 2015: 4). Disinilah letak multidimensional dari lembaga keimigrasian sebagai pengemban fungsi penegakan hukum, penjaga kedaulatan negara, dan fasilitator pembangunan kesejahteraan masyarakat. Pemberlakuan kebijakan bebas visa tentu tidak sesuai dengan prinsip yang terkandung dalam kebijakan selektif keimigrasian. Oleh karenanya, atas dasar kemanfaatan dan kepentingan umum, keberadaan kebijakan bebas visa perlu untuk ditinjau kembali.

\section{B. Menakar Kedaulatan Negara dalam Perspektif Keimigrasian: Studi Kasus Kontemporer}

\section{Dampak Implementasi Kebijakan Bebas Visa}

Pasca diberlakukannya Peraturan Presiden Nomor 21 Tahun 2016 tentang Bebas Visa Kunjungan, maka jumlah warga negara asing ke Indonesia meningkat tajam. Berdasarkan data dari Badan Pusat Statistik (BPS), jumlah kunjungan wisatawan mancanegara atau wisman dalam arti luas ke Indonesia pada Februari 2016 mencapai 888,3 ribu kunjungan, naik 5,26 persen dibanding kunjungan Februari 2015. Begitu pula, jika dibandingkan dengan Januari 2016, mengalami kenaikan sebesar 9,09 persen. Secara kumulatif, pada Januari-Februari 2016, jumlah kunjungan wisman dalam arti luas ke Indonesia mencapai 1,70

juta kunjungan atau naik 4,46 persen dibandingkan jumlah kunjungan wisman pada periode yang sama tahun sebelumnya yang berjumlah 1,63 juta kunjungan (Syahrin, 2016: 33-35). Namun, hampir dua tahun sejak diberlakukannya kebijakan bebas visa, praktiknya telah banyak menimbulkan kerawanan politik, hukum, keamanan, kedaulatan negara dari perspektif keimigrasian. Berikut dampak yang ditimbulkan dari kebijakan bebas visa tersebut, yaitu:

\section{a. Pelayanan Keimigrasian}

Dengan diberlakukannya kebijakan bebas visa kunjungan telah memberikan dampak yang sangat signifikan bagi bidang pelayanan keimigrasian bagi orang asing. Pelayanan perpanjangan izin tinggal dan pembelian Visa on Arrival (VOA) mengalami penurunan yang sangat signifikan. Hal ini dikarenakan, negara yang diberikan fasilitas bebas visa kunjungan sebagian besar merupakan negara-negara subyek dari VOA.

Dari hasil wawancara dengan petugas pendaratan di Tempat Pemeriksaan Imigrasi (TPI) pada Bandar Udara Soekarno Hatta, dijelaskan bahwa dalam sehari biasanya petugas pendaratan dapat menerima VOA sebanyak 400 voucher, namun kini hanya 50 voucher VOA. Berdasarkan laporan rekonsiliasi VOA antara pihak Imigrasi dengan Bank Rakyat Indonesia (BRI) tahun 2014 pada Kantor Imigrasi Kelas 1 Khusus Soekarno Hatta terjual sebanyak 1.183.721 voucher. Sedangkan pada tahun 2015 mengalami penurunan penjualan sebanyak 905.430 voucher. Penurunan juga dialami oleh Kantor Imigrasi Kelas I Ngurah Rai.

Tabel 1.

\section{Statistik Pemberian dan Perpanjangan VOA} pada Kantor Imigrasi Kelas I Ngurah Rai

\begin{tabular}{|l|l|l|l|}
\hline No. & Kegiatan & 2014 & 2015 \\
\hline 1. & Pemberian VOA & 3.044 .292 & 2.011 .857 \\
\hline 2. & Perpanjangan VOA & 27.258 & 25.742 \\
\hline
\end{tabular}

Sumber: Statistik Kegiatan Keimigrasian Kantor Imigrasi Klas 1 Khusus Ngurah Rai Tahun 2014-2015

Berdasarkan data tersebut terjadi penurunan jumlah permohonan perpanjangan izin tinggal visa kunjungan saat kedatangan sebanyak 5,5\%. Jadi, dapat disimpulkan setelah diberlakukannya kebijakan bebas visa kunjungan berdampak pada fungsi pelayanan keimigrasian, khususnya penurunan jumlah permohonan pemberian VOA dan perpanjangan Izin Tinggal untuk VOA.

\section{b. Penegakan Hukum}

Penegakan hukum keimigrasian dilaksanakan melalui 2 (dua) cara, yaitu dengan tindakan administratif keimigrasian dan penyidikan sesuai Undang-Undang Nomor 6 Tahun 2011 tentang Keimigrasian. Setelah dikeluarkan Kebijakan Bebas Visa Kunjungan Tahap I (satu) yang 
dikeluarkan pada bulan Juni 2015 serta Kebijakan Bebas Visa Kunjungan tahap II (dua) pada bulan September 2015 membawa dampak terhadap penegakan hukum keimigrasian.

Direktorat Jenderal Imigrasi mencatat ada 9.226 pelanggaran yang dilakukan WNA di Indonesia pada tahun 2015. Jumlah ini meningkat dibanding tahun sebelumnya. Jumlah pelanggaran yang telah ditindak dengan sanksi administratif oleh kantor Imigrasi Kelas I Khusus Soekarno Hatta pada Orang asing yang menggunakan izin tinggal Bebas Visa Kunjungan terdapat 8 orang, yang ditangkap dari hasil operasi pengawasan Orang Asing pada bulan Oktober.

Sedangkan Kebijakan BVK tahap II (dua) baru dikeluarkan pada bulan September 2015. Maka dapat dikatakan baru sebulan Kebijakan BVK diberlakukan sudah terdapat pelanggaran yang cukup banyak. Penegakan hukum tindakan administratif keimigrasian semenjak diberlakukannya BVK bagi OA yang melakukan pelanggaran jumlahnya sangat meningkat hal tersebut dapat dilihat dari hasil Laporan Akuntabilitas Kinerja Institusi Pemerintah Direktorat Jenderal Imigrasi Tahun 2015.

Tabel 2

Jumlah Tindakan Administratif Keimigrasian

\begin{tabular}{|c|l|l|l|}
\hline No. & Tindakan Administratif Keimigrasian & \multicolumn{1}{|c|}{$\mathbf{2 0 1 4}$} & $\mathbf{2 0 1 5}$ \\
\hline 1 & $\begin{array}{l}\text { Pelaku Pelanggaran Keimigrasian yang di } \\
\text { Ditindak }\end{array}$ & 1.932 & 2.508 \\
\hline
\end{tabular}

Sumber: Laporan Akuntabilitas Kinerja Institusi Pemerintah

Direktorat Jenderal ImigrasiTahun 2015

Dari data tersebut terjadi peningkatan sebanyak $23 \%$ tindakan administratif yang telah dilakukan imigrasi semenjak diberlakukan kebijakan bebas visa kunjungan ini. Untuk penegakan hukum dalam tindak pidana dalam laporan Kinerja Akuntabilitas institusi Pemerintah Direktorat Jenderal Imigrasi pada tahun 2014 Direktorat Jenderal Imigrasi dapat menangani 27 kasus, namun jumlah ini meningkat hingga 45 kasus.

\section{c. Keamanan Negara}

Sejak berlakunya kebijakan bebas visa, Direktorat Penyidikan dan Penindakan Keimigrasian telah melakukan pemeriksaan terhadap 270 WNA pelaku tindak pidana keimigrasian yang diduga melakukan penipuan secara online (cyber crime )hasil pelimpahan dari Polda Metro Jaya, Kantor Imigrasi, Bareskim dan Operasi Gabungan. Dilanjutkan dengan pelaksanaan proses penyidikan sebanyak 45 kasus tindak pidana keimigrasian di 15 Kantor Imigrasi. Realisasi yang dicapai adalah 140,6\% dari target Rencana Kerja TA 2015.

Berdasarkan laporan Badan Narkotika Nasional (BNN), disampaikan bahwa sejak diberlakukan kebijakan bebas visa terjadi peningkatan jumlah perdagangan narkotika yang signifikan dari warga negara Tiongkok. Tidak hanya itu, kini Indonesia harus bersiap menerima eksodus tenaga kerja Tiongkok baik itu legal ataupun illegal.

Peningkatan jumlah pelanggaran yang dilakukan oleh Orang Asing yang berasal dari negara-negara subyek bebas visa seharusnya menjadi pertimbangan dalam memberikan kebijakan tersebut (Ethier, 2016: 56-71). Pendekatan ekonomi dalam bidang Imigrasi tidak boleh menyampingkan faktor keamanan negara yang menjadi tujuan dari banyak kepentingan bagi orang asing (Syahrin, 2017: 168-178).

\section{d. Fasilitator Pembangunan Kesejahteraan Masyarakat}

Kebijakan bebas visa kunjungan tidak hanya mempengaruhi pariwisata, namun juga menimbulkan dampak bagi Imigrasi khususnya dalam sektor Penerimaan Negara Bukan Pajak (PNBP) Imigrasi. Dengan adanya kebijakan bebas visa kunjungan maka jumlah penggunaan visa kunjungan saat kedatangn berkurang. Orang asing yang datang ke Indonesia lebih memilih menggunakan fasilitas bebas visa kunjungan daripada harus membayar US\$ 35.

Penurunan penggunaan VOA juga sangat dirasakan oleh Petugas Imigrasi di Tempat Pemeriksaan Imigrasi pada Bandar Udara Internasional Soekarno Hatta. Sebelum 
berlakunya kebijakan bebas visa, satu petugas dapat memberikan 400 voucher dalam satu shift. Namun setelah dikeluarkan kebijakan bebas visa kunjungan, jumlah voucher yang diberikan mengalami penurunan hingga 50 voucher selama satu shift.

Penurunan jumlah penggunaan fasilitas VOA juga terlihat pada laporan rekonsiliasi VOA antara Imigrasi pada Kantor Imigrasi Kelas I Khusus Soekarno Hatta dengan Bank Rakyat Indonesia (BRI). Pada tahun 2015, jumlah voucher yang terjual adalah 905.403. Angka ini menurun dibandingkan tahun 2014, yaitu sebanyak
1.183.721 dengan jumlah Rp. 425.080.952. Hal ini berarti terjadi penurunan hingga 23,5\% (LAKIP Ditjenim Tahun 2015).

Tren penurunan juga terjadi pada Bandar Udara Internasional Ngurah Rai. Penurunan penggunaan VOA mencapai $34 \%$ pada tahun 2015. Padahal di tahun 2014 jumlah voucher VOA yang terjual sebanyak 3.044.292. Sedangkan pada tahun 2015 adalah sebanyak 2.011.857 (LAKIP Ditjenim Tahun 2015). Penurunan persetujuan VOA juga dapat terlihat dalam Laporan Akuntabilitas Institusi Pemerintah Direktorat Jenderal Imigrasi Tahun 2015 sebagai berikut.

Tabel 3.

Jenis Persetujuan Visa

\begin{tabular}{|l|l|l|l|}
\hline No. & \multicolumn{1}{|c|}{ Jenis Persetujuan Visa } & \multicolumn{1}{|c|}{$\mathbf{2 0 1 4}$} & \multicolumn{1}{|c|}{$\mathbf{2 0 1 5}$} \\
\hline 1 & Visa Kunjungan & 17.367 & 17.684 \\
\hline 2 & Visa Kunjungan Beberapa Kali & 16.206 & 25.963 \\
\hline 3 & Visa Kunjungan Saat Kedatangan & 3.706 .062 & 3.220 .343 \\
\hline 4 & Visa Izin Tinggal Terbatas & 79.062 & 77.418 \\
\hline 5 & Visa Izin Tinggal Terbatas Saat Kedatangan & 2.865 & 3.701 \\
\hline 6 & Work and Holiday Visa & - & 3 \\
\hline \multicolumn{2}{|l|}{ Total Persetujuan Visa } & 3.827 .412 & 3.345 .112 \\
\hline
\end{tabular}

Sumber : Laporan Akuntabilitas Institusi PemerintahDirektorat Jenderal Imigrasi Tahun 2015

Persetujuan visa kunjungan saat kedatangan pada tahun 2014 berjumlah 3.706.062 sedangkan pada tahun 2015 berjumlah 3.220 .343 yang mana angka tersebut menunjukkan penurunan 485.719. Penurunan penggunaan VOA ini berdampak langsung terhadap PNBP pada Kantor Imigrasi yang didapat dari penjualan voucher VOA. Contohnya, pada Kantor Imigrasi Klas 1 Khusus Soekarno Hatta yaitu sebanyak Rp 678.351.265(LAKIP Ditjenim Tahun 2015).

Tabel 4.

Nilai Rupiah Pemberian VOA

\begin{tabular}{|l|l|l|}
\hline \multicolumn{1}{|c|}{ Tahun } & \multicolumn{1}{|c|}{ Jumlah Voucher } & \multicolumn{1}{c|}{ Jumlah Rupiah } \\
\hline 2014 & 1.183 .721 & 425.080 .952 .350 \\
\hline 2015 & 905.430 & 418.297 .439 .700 \\
\hline
\end{tabular}

Sumber : Laporan Rekonsiliasi VOA antara Kantor Imigrasi Klas 1

Khusus Soekarno Hatta dengan Bank Rakyat Indonesia (BRI)

Penurunan jumlah PNBP Yang didapatkan dari penjualan VOA hampir dialami oleh semua Kantor Imigrasi, sehingga mengakibatkan target PNBP Direktorat Jenderal Imigrasi tidak tercapai. Pencapaian target PNBP Keimigrasian sangat dipengaruhi dengan diterbitkannya Peraturan Presiden mengenai kebijakan bebas visa kunjungan. Sektor penyumbang PNBP yang paling terpengaruh yaitu dalam hal target penerbitan visa kunjungan saat kedatangan.

Tabel 5.

Presentase Target dan Realiasi PNBP Imigrasi

\begin{tabular}{|l|l|l|l|}
\hline \multirow{2}{*}{ Tahun } & \multicolumn{2}{|c|}{ PNBP } & \multirow{2}{*}{$\begin{array}{c}\text { PERSENTASE } \\
(\%)\end{array}$} \\
\cline { 2 - 4 } & \multicolumn{1}{|c|}{ Target } & \multicolumn{1}{|c|}{ Realisasi } \\
\hline 2014 & $2.186 .759 .586 .693,-$ & $2.935 .742 .059 .630,-$ & 134,25 \\
\hline 2015 & $3.310 .310 .598 .000,-$ & $3.079 .132 .607 .426,-$ & 93,01 \\
\hline
\end{tabular}

Sumber : Laporan Akuntabilitas Institusi Pemerintah Direktorat Jenderal Imigrasi Tahun 2015 
Persoalan politik, hukum, dan keamanan pasca diberlakukannya kebijakan bebas visa juga berdampak pada membeludaknya jumlah eksodus warga negara Tiongkok ke Indonesia (Syahrin, 2016: 33-35). Dikarenakan merupakan subjek bebas visa, tidak sedikit warga negara Tiongkok yang menyalahgunakan kebijakan tersebut untuk bekerja secara ilegal di Indonesia.

Keberadaan mereka juga menimbulkan keresahan bagi masyarakat di daerah. Banyaknya pelanggaran menjadi sisi lain yang tidak terbantahkan sebagai ekses diberlakukannya kebijakan bebas visa.

Tabel 6.

Subjek Negara Pelanggar Bebas Visa

\begin{tabular}{|l|l|l|}
\hline No. & \multicolumn{1}{|c|}{ Negara } & Jumlah \\
\hline 1 & Tiongkok & 1.180 \\
\hline 2 & Afganistan & 411 \\
\hline 3 & Bangladesh & 172 \\
\hline 4 & Filipina & 151 \\
\hline 5 & Irak & 127 \\
\hline
\end{tabular}

Sumber : Laporan Akuntabilitas Institusi Pemerintah Direktorat Jenderal Imigrasi Tahun 2015

Pasca diberlakukannya kebijakan bebas visa kunjungan, terdapat beberapa pelanggaran yang dilakukan oleh orang asing antara lain adalah sebagai berikut: (Athira, 2017: 64)

1) Terdapat 8 (delapan) pekerja illegal asal Tiongkok diamankan pada Juni 2016 karena tidak memiliki dokumen resmi di Desa Galang Batang, Kecamatan Kijang, Bintan, Kepulauan Riau;

2) Penyalahgunaan bebas visa kunjungan oleh seorang warga negara Singapura pada bulan Mei 2016 di Kabupaten Kubu Raya, Kalimantan Barat. Yang bersangkutan melakukan usaha penampungan tempurung dan sabut kelapa untuk diekspor ke Tiongkok

3) Pada bulan Mei 2016, 2 (dua) warga negara Tiongkok diamankan oleh pihak imigrasi karena menggunakan bebas visa kunjungan untuk bekerja di tambang emas di Kelurahan Pobya, Kecamatan Palu Timur, Sulawesi tengah. Bahkan visa kunjungan tersebut sudah melampaui batas (overstay) selama 70 hari;

2. Eksistensi Pengungsi dan Pencari Suaka: Kedaulatan Negara dan HAM Internasional

\section{a. Dialektika}

Keberadaan pencari suaka dan pengungsi di Indonesia tidak dapat dipisahkan dari intervensi lembaga internasional dengan manjadikan hak asasi manusia sebagai dasar pembenarannya. Prinsip yang terkenal dalam hukum pengungsi adalah prinsip larangan pengusiran bagi pengungsi dan pencari suaka ke negara asalnya (nonrefoulement) yang diatur dalam Pasal 33 Ayat (1) Konvensi Tahun 1951 tentang Status Pengungsi (Basri, 2013: 76). Pasal tersebut menetapkan bahwa negara-negara pihak pada konvensi ini tidak boleh mengusir atau mengembalikan seorang pengungsi, dengan cara apapun, ke perbatasan wilayah negara pihak yang akan mengancam kehidupan maupun kebebasan pengungsi karena alasan ras, agama, kebangsaan, keanggotaan pada kelompok sosial tertentu ataupun karena opini politiknya (Starke, 2013: 202). Pasal 33 Ayat (1) Konvensi Tahun 1951 yang berisi prinsip non-refoulement ini termasuk dalam pasal-pasal yang tidak dapat direservasi dan prinsip ini pun mengikat negara-negara bukan peserta Konvensi Tahun 1951 (Patrnogic, 2016: 19).

Prinsip non-refoulement sebagaimana tercantum dalam Pasal 33 ayat (1) Konvensi Tahun 1951 merupakan dasar dari perlindungan internasional terhadap pengungsi (Kusumaatmadja dan Agoes, 2013: 16-18). Substansi dari prinsip non-refoulement adalah jaminan suatu negara untuk tidak akan mengusir atau mengembalikan seorang pengungsi dengan cara appaun ke negara asalnya dimana kehidupan dan kebebasannya akan terancam. Sesuai dengan kriteria yang ditetapkan Pasal 31 dan Pasal 33 Ayat (1) Konvensi Tahun 1951, baik kedatangan secara tidak sah maupun kegagalan melaporkan kepada otoritas yang berwenang dalam batas waktu yang telah ditentukan tidak dapat dipertimbangkan 
sebagai alasan formal untuk mengesampingkan seseorang dari status pengungsi(Parthiana, 2016: 25-27).

Pasal 33 Ayat (1) Konvensi Tahun 1951 tentang Status Pengungsi menyatakan bahwa:

"Tidak ada Negara Pihak yang akan mengusir atau mengembalikan ("refouler") pengungsi dengan cara apa pun ke perbatasan wilayahwilayah dimana hidup dan kebebasannya akan terancam karena ras, agama, kebangsaan, keanggotaan pada kelompok sosial tertentu atau opini politiknya."

Namun, keberlakuan prinsip non-refoulement bagi pencari suaka dan pengungsi tidak dapat diterapkan secara masif dan memaksa kepada suatu negara. Prinsip ini tidak dapat berlaku mutlak. Walaupun, normanya bersifat memaksa (jus cogens), namun penerapannya sangat kondional, tergantung pada urgensi dan kebutuhannnya bagi negara peserta. Apalagi terhadap Indonesia, yang sampai saat ini bukan merupakan negara pihak Konvensi Tahun 1951.

Pembatasan atau pengecualian prinsip nonrefoulement diatur dalam Pasal 33 ayat (2) Konvensi Tahun 1951 tentang Status Pengungsi, yang menyatakan bahwa:

"Namun, keuntungan dari ketentuan ini tidak boleh diklaim oleh pengungsi di mana terdapat alasan-alasan yang layak untuk menganggap sebagai bahaya terhadap keamanan negara dimana ia berada, atau karena telah dijatuhi hukuman oleh putusan hakim yang bersifat final atas tindak pidana sangat berat ia merupakan bahaya bagi masyarakat negara itu."

Diskurus penanganan pencari suaka dan pengungsi menjadi rumit, ketika pemerintah mengeluarkan Peraturan Direktur Jenderal Imigrasi Nomor: IMI-0352.GR.02.07 tentang Penanganan Imigran Ilegal yang Menyatakan Diri sebagai Pencari Suaka dan Pengungsi, yang ditandatangani pada tanggal 19 April 2016. Berdasarkan Pasal 2 Ayat (2) Konvensi Tahun 1951, secara tersirat mengakomodir prinsip nonrefoulement yang menjelaskan bahwa terhadap orang asing yang menyatakan diri sebagai pencari suaka dan pengungsi pada saat masuk ke wilayah Indonesia, dilakukan penanganan pada kesempatan pertama. Jelas ini bertentangan dengan prinsip kebijakan selektif keimigrasian, yang dianut oleh Direktorat Jenderal Imigrasi. Alasan yang mendasari adalah: (i) Indonesia bukan negara pihak Konvensi Tahun 1951, (ii) keberadaan pengungsi telah mengganggu ketertiban umum, (iii) instrument hukum keimigrasian hanya mengenal istilah regular migrant dan irregular migrant. Terhadap irregular migrant, maka tindakan yang diberikan adalah deportasi dan penyidikan, dan (iv) persoalan kemanusiaan nasional harus menjadi prioritas tanpa mengabaikan kepentingan pengungsi internasional.

Setahun setelah ditetapkannya peraturan tersebut, kini pemerintah mengeluarkan Peraturan Presiden Nomor 125 Tahun 2016 tentang Penanganan Pengungsi dari Luar Negeri. Dalam bagian konsiderans peraturan preseiden tersebut, tidak disebutkan sama sekali kepentingan filosofis, yuridis, dan sosiologis dari aspek keimigrasian. Bahkan, Undang-Undang Nomor 6 Tahun 2011 tentang Keimigrasian tidak dimasukkan dalam bagian mengingat. Alhasil norma yang dirumuskan pun jauh dari semangat penegakan hukum, pengamanan, dan kedaulatan negara. Padahal fungsi keimigrasian adalah untuk memastikan agar setiap orang asing yang masuk dan keluar wilayah Indonesia membawa manfaat dan tidak merugikan Indonesia(Syahrin, 2015: 29-31). Belum lagi, rumah Detensi Imigrasi yang fungsi awalnya hanya sebagai tempat penampungan sementara bagi orang asing yang akan dikenakan tindakan adminstratif keimigrasian (immigratoir), kini telah berubah menjadi tempat penampungan pencari suaka dan pengungsi. Faktanya, hampir semua Rumah Detensi Imigrasi di Indonesia mengalami kelebihan kapasitas (over capacity), karena terlalu banyak menampung pencari suaka dan pengungsi (Indra, 2015: 55)

\section{b. Kerawanan Berbagai Aspek}

Ada beberapa dampak serius yang ditimbulkan dari semakin meningkatnya keberadaan imigran ilegal di Indonesia. Dampak yang mungkin tidak dirasakan sekarang, tetapi beberapa tahun ke depan.

Dampak secara ideologi. Keberadaan imigran ilegal (baca: pencari suaka dan pengungsi) di Indonesia, akan berdampak pada falsafah dan pandangan hidup negara Indonesia. Perbedaan latar belakang bangsa, bahasa, dan budaya tentu berpotensi merubah cara pandang dan kehidupan masyarakat. Nilai-nilai bangsa yang selama ini menjadi kesepakatan bersama, akan tercancam 
apabila pola dan perilaku yang dibawa oleh para imigran ilegal tidak sesuai dengan Pancasila sebagai ide bangsa (staat idee).

Dampak secara politik. Dengan semakin banyaknya manusia perahu yang melintasi perairan Indonesia, lalu semakin maraknya kasus penyelundupan manusia dan perdagangan orang yang menjadikan Australia sebagai negara tujuan, maka menyebabkan hubungan bilateral antara Indonesia dan Australia menjadi tidak harmonis. Belum lagi adanya kasus penyadapan yang dilakukan oleh Australia terhadap pemerintahan Indonesia, akan membuat situasi menjadi memanas (Syahrin, 2014: 30-35). Turn back a boat policy dan politik hukum keimigrasian yang tidak populer dari Australia terhadap para imigran (legal dan ilegal), akan memicu ketidakharmonisan hubungan di antara kedua negara, bahkan bagi negara pihak ketiga penerima pencari suaka dan pengunsi (Papua Nugini dan Selandia Baru) (Fernando, 2014: 1).

Dampak secara sosial budaya. Adanya perbedaan fisik, bahasa, dan budaya akan mempengaruhi sistem sosial dan budaya masyarakat Indonesia. Mayoritas pencari suaka dan pengungsi yang masuk ke wilayah Indonesia adalah berasal dari negara kawasan Asia Selatan, Asia Tengah, dan Asia Barat, dan Afrika yang merupakan negara rawan konflik. Perilaku mereka cenderung agresif dan sukar diatur. Hal ini tentu akan meresahkan warga sekitar, yang daerahnya dijadikan tempat penampungan sementara di luar Rudenim. Belum lagi pengaruh agama dan kepercayaan yang dibawa dari negara asal. Kemudian kecemburuan sosial yang mungkin akan timbul akibat adanya perlakuan berbeda (baca: eksklusif) yang diberikan oleh pemerintah Indonesia terhadap pencari suaka dan pengungsi (Schahter, 2013: 254).

Dampak potensi keimigrasian. Pola dan praktik ekspansi imigran ilegal ke Indonesia membawa konsekuensi keimigrasian tersendiri, terutama pada aspek pelanggaran dan kejahatan keimigrasian, yang meliputi pemalsuan dokumen perjalanan (paspor), pemalsuan visa, izin tinggal, bahkan penyalahgunaan izin tinggal. Modusmodus demikian harus menjadi perhatian serius bagi Imigrasi Indonesia, guna mengantisipasi masuknya imigran ilegal ke wilayah Indonesia

Indonesia merupakan negara yang sangat strategis bagi para imigran ilegal (pengungsi dan pencari suaka) yang hendak ke Australia. Banyak para pencari suaka yang pada awalnya hanya singgah ke Indonesia untuk melanjutkan perjalanan ke Australia, malah menetap tinggal di Indonesia. Kondisi ini semakin pelik ketika Australia telah melakukan kerja sama dengan Papua Nugini, untuk mengalihkan para pencari suaka yang masuk ke Australia untuk dikirim ke negara pihak ketiga (Berry, 2017: 5-34).

Selain itu kebijakan pemindahan pencari suaka (baca: manusia perahu) ke Negara ketiga, kebijakan Australia lainnya yang merugikan Indonesia adalah kebijakan "turn back the boat", penolakan status bagi pencari suaka per 1 Juli 2014, pemberian visa sementara (bukan izin menetap) dan "operation sovereign border policy". Kebijakan-kebijakan tersebut tentu akan membuat posisi Indonesia semakin sulit dalam mengatasi arus gelombang imigran illegal yang masuk ke wilayah Indonesia. Tren yang terjadi saat ini, adanya peningkatan invansi imigran ilegal yang luar biasa dari tahun ke tahun. Akibatnya, semakin banyak para imigran illegal (pengungsi dan pencari suaka) yang mengubah tujuan negara dari Australia ke Indonesia.

\section{Eksodus Tenaga Kerja Asing Tiongkok a. Paket Kebijakan Investasi Pro Asing}

Kebijakan Bebas Visa Kunjungan dan perubahan persyaratan tenaga kerja asing adalah sedikit regulasi yang membuka pintu arus masuknya warga negara Tiongkok ke Indonesia. Membeludaknya jumlah tersebut tidak terlepas dari kebijakan yang dibuat oleh Presiden Joko Widodo, yaitu Kebijakan Bebas Visa Kunjungan. Secara hukum internasional, kebijakan ini harus memperhatikan asas resiprositas yang menimbulkan hubungan timbal balik di antara negara pihak (Macedo, 2014: 3739). Namun faktanya tidak demikian. Kebijakan Bebas Visa yang digulirkan oleh pemerintah, tidak mengindahkan asas ini. Misal, Indonesia memberikan akses bebas visa kunjungan kepada beberapa negara seperti Amerika Serikat, Inggris, Belanda, dan Tiongkok. Namun negara-negara tersebut tidak memberikan kebijakan sebaliknya kepada Indonesia.

Kebijakan ini diawali dengan dibentuknya Peraturan Presiden Nomor 69 Tahun 2015, kemudian diubah dengan Peraturan Presiden Nomor 104 Tahun 2015, hingga yang terakhir 
Peraturan Presiden Nomor 21 Tahun 2016 yang memberikan Bebas Visa Kunjungan kepada 169 negara.

Alasan ekonomi dan pariwisata yang menjadi dasar pemberlakukan kebijakan Bebas Visa Kunjungan tidaklah tepat. Sejauh ini belum ada angka pasti yang menyebutkan seberapa besar pengaruh positif bagi perekonomian bangsa terkait dengan kebijakan tersebut (Bond and Chen, 2017: 315-328). Dari sudut pandang legalitas, Kebijakan ini bertentangan dengan Pasal 43 ayat (2) UU No. 6 Tahun 2011 yang mensyaratkan bahwa orang asing dapat dibebaskan dari kewajiban memiliki visa apabila telah ditetapkan dalam Peraturan Presiden dengan memperhatikan asas timbal balik dan asas manfaat. Namun, faktanya tidak demikian. Tiongkok tidak memberikan Bebas Visa Kunjungan kepada Indonesia. Sehingga, menurut hemat penulis kebijakan tersebut lebih banyak menimbulkan kerugian dibandingkan manfaatnya.

Selanjutnya di bidang ketenagakerjaan. Pemerintah dalam waktu kurang dari dua tahun, telah merevisi Peraturan Menteri Tenaga Kerja dan Transmigrasi (Permenakertrans) No. 12 Tahun 2013 tentang Tata Cara Penggunaan Tenaga Kerja Asing dengan mengeluarkan Permenakertrans Nomor 16 Tahun 2015 tentang Tata Cara Penggunaan Tenaga Kerja Asing. Dua peraturan ini dilahirkan dari rezim pemerintahan yang berbeda. Revisi dilakukan pada masa pemerintahan Presiden Joko Widodo yang menuntut percepatan pembangunan dengan mendatangkan tenaga kerja Tiongkok. Perubahan krusial terdapat pada ketentuan yang menghilangkan syarat pendidikan Strata-1 dan kemampuan berbahasa Indonesia bagi tenaga kerja asing.

Tidak hanya itu, ketentuan yang mengharuskan suatu perusahaan apabila ingin memperkerjakan satu tenaga kerja asing, harus merekrut sepuluh tenaga kerja Indonesia, kini juga dihapus oleh Kementerian Tenaga Kerja dan Transmigrasi (Kemenakertrans). Semestinya, ketentuan tentang persyaratan tenaga kerja asing ini harus menjadi perhatian serius, khususnya terkait dengan posisi jabatan, jumlah, prosedur, dan waktu yang harus dibatasi. Disini terlihat jelas bagaimana usaha dari pemerintah untuk mengubah aturan yang sudah ada agar memudahkan tenaga kerja asing masuk ke Indonesia. Harusnya, dalam kebijakan tersebut pemerintah juga perlu memperhatikan kepentingan warga lokal dengan melindungi dan memberikan jaminan yang sama dengan tenaga kerja asing (Syahrin, 2016: 33-35).

Sejak diberlakukannya kebijakan Bebas Visa Kunjungan, maka jumlah warga negara asing ke Indonesia meningkat tajam. Berdasarkan data dari Badan Pusat Statistik (BPS), jumlah kunjungan wisatawan mancanegara atau wisman dalam arti luas ke Indonesia Februari 2016 mencapai 888,3 ribu kunjungan, naik 5,26 persen dibanding kunjungan Februari 2015. Begitu pula, jika dibandingkan dengan Januari 2016, mengalami kenaikan sebesar 9,09 persen. Secara kumulatif, Januari-Februari 2016, jumlah kunjungan wisman dalam arti luas ke Indonesia mencapai 1,70 juta kunjungan atau naik 4,46 persen dibandingkan jumlah kunjungan wisman pada periode yang sama tahun sebelumnya yang berjumlah 1,63 juta kunjungan. Dari angka tersebut, sekitar tiga puluh persen didominasi oleh warga negara Tiongkok.

Berdasarkan data dari Direktorat Jenderal Imigrasi pada tahun 2014, jumlah pelanggaran keimigrasian yang dilakukan warga negara Tiongkok sangat mendominasi. Perbandingan antara jumlah pelanggaran dan jumlah perlintasan yang dilakukan oleh warga negara Tiongkok adalah 3.816 berbanding 884.743. Jumlah tersebut adalah yang tertinggi bila dibandingkan dengan negara-negara laini.

Berdasarkan data yang dirilis oleh Kemenakertrans, pada Tahun 2014 ada sekitar 68.000 tenaga kerja asing yang bekerja di Indonesia dengan memiliki Izin Menggunakan Tenaga Kerja Asing (IMTA). Lalu, pada tahun 2015 jumlah tenaga kerja asing di Indonesia berjumlah 69.000. Untuk bulan Juni 2016, telah menyentuh angka 43.000 orang. Jumlah tersebut diperkirakan akan terus mengalami peningkatan.

Hingga Juni 2016, tenaga kerja Tiongkok yang bekerja di Indonesia, berjumlah 14.500 tenaga kerja yang mendapatkan izin kerja secara sah. Sedangkan pada Tahun 2015 berjumlah 15.000 orang dan pada Tahun 2014 berjumlah 16.800. Berdasarkan data tersebut, jumlah tenaga kerja Tiongkok yang datang ke Indonesia mengalami kenaikan. Tren tersebut dipicu karena adanya hasil kerjasama bilateral G2G antara Indonesia dan Tiongkok di sektor perekonomian.

Angka tersebut telah melampaui jumlah imigran ilegal (pencari suaka dan pengungsi) di seluruh Indonesia yang menurut data Direktorat Jenderal Imigrasi per 30 September 2015, 
mencapai 13.405 orang. Perbedaan yang cukup jauh mengingat migrasi warga negara Tiongkok ke Indonesia meningkat tajam hanya dalam kurun waktu kurang dari tiga tahun.

\section{b. Impikasi Hukum}

Berdasarkan ketentuan Peraturan Menteri Tenaga Kerja dan Transmigrasi (Permenakertrans) No. 16 Tahun 2015 dan Keputusan Menteri Tenaga Kerja dan Transmigrasi No. 15 Tahun 2015, tenaga kerja asing yang bekerja di Indonesia hanya dapat menduduki jabatan tertentu, memiliki keahlian khusus, dan profesional di bidangnya. Normatifnya, ekspatriat yang dapat bekerja di Indonesia adalah para pekerja spesialis yang keahliannya tidak dimiliki oleh masyarakat lokal.

Fakta di lapangan banyak ditemui tenaga kerja Tiongkok yang melakukan pekerjaan tidak sesuai Izin Menggunakan Tenaga Kerja Asing (IMTA) yang diberikan. Katakanlah, dalam IMTA disebutkan pekerjaannya adalah Engineering Specialist atau Electronical Specialist, namun kenyataannya mayoritas mereka melakukan pekerjaan kasar, seperti mengaduk semen, memasang batu bata, mengangkat batu dan besi, bahkan pernah ditemukan sebagai tukang masak (koki) pada perusahaan tersebut. Mayoritas tenaga kerja Tiongkok (ilegal) adalah unskill worker, yang bekerja bukan atas dasar kualifikasi dan keahlian tertentu.

Harus disadari, mayoritas pelanggaran keimigrasian yang dilakukan oleh warga negara Tiongkok di Indonesia adalah melakukan kegiatan yang tidak sesuai dengan izin tinggal yang telah diberikan. Selain itu juga tidak dapat menunjukkan paspor dan izin tinggal, karena dipegang oleh pihak sponsor. Sebagian besar dikenakan Pasal 116 dan Pasal 122 huruf a UU No. 6 Tahun 2011 tentang Keimigrasian.

Pasal 116 UU No. 6 Tahun 2011 menentukan bahwa "Setiap orang asing yang tidak melakukan kewajibannya sebagaimana dimaksud dalam Pasal 71 dipidana dengan pidana kurungan paling lama 3 (tiga) bulan atau pidana denda paling banyak Rp. 25.000.000 (dua puluh lima juta rupiah)." Pasal 71 mengatur bahwa "Setiap orang asing yang berada di wilayah Indonesia wajib: (a) memberikan segala keterangan yang diperlukan mengenai identitas diri dan/atau keluarganya serta melaporkan setiap perubahan status sipil, kewarganegaraan, pekerjaan, Penjamin, atau perubahan alamatnya kepada Kantor
Imigrasi setempat; atau (b) memperlihatkan dan menyerahkan Dokumen Perjalanan atau Izin Tinggal yang dimilikinya apabila diminta oleh Pejabat Imigrasi yang bertugas dalam rangka pengawasan Keimigrasian."

Kemudian Pasal 122 huruf a UU No. 6 Tahun 2011 mengatur bahwa "Setiap orang asing yang dengan sengaja menyalahgunakan atau melakukan kegiatan yang tidak sesuai dengan maksud dan tujuan pemberian izin tinggal yang diberikan kepadanya, dipidana dengan pidana penjara paling lama 5 (lima) tahun dan pidana denda paling banyak Rp. 500.000.000 (lima ratus juta rupiah)." Kedua pasal ini merupakan pasal yang paling banyak dilanggar oleh warga negara asing, khususnya tenaga kerja yang berasal dari Tiongkok.

Pada tahun 2014, Penulis yang tergabung dalam Tim Pengawasan dan Penindakan Keimigrasian Kantor Imigrasi Kelas II Muara Enim melakukan pengawasan keimigrasian terhadap keberadaan orang asing di PT. Priamanaya Energy yang bertempat di Kabupaten Lahat, Sumatera Selatan. Ditemukan kurang lebih 350 tenaga kerja Tiongkok yang tidak sesuai dengan izin tinggal diberikan. Hampir semuanya menggunakan Visa Kunjungan Satu Kali Perjalanan (B.211), bahkan sebagian besar dari mereka telah overstay di Indonesia. Berdasarkan data paspor dan pengamatan fisik, tidak sedikit dari mereka adalah pekerja di bawah umur. Tentu selain adanya pelanggaran keimigrasian, ada dugaan kejahatan sindikat perdagangan manusia (human traficking) di dalam kegiatan tersebut.

\section{KESIMPULAN}

Berdasarkan uraian di atas, maka dapat ditarik kesimpulan sebagai berikut. Konsep kedaulatan negara dalam perspektif keimigrasian dapat tercermin dari pelbagai peraturan berikut, yaitu (i) Pasal 1 Angka (1) jo. Pasal 1 Angka (3) UU No. 6 Tahun 2011 yang menjelaskan tentang peran penting keberadaan keimigrasian beserta tugas dan fungsinya dalam menjaga kedaulatan negara; (ii) Pasal 22 Ayat (2) UU No. 6 Tahun 2011 yang menjelaskan tentang keberadaan Area Imigrasi sebagai batas imajiner wilayah kedaulatan NKRI dalam Tempat Pemeriksaan Imigrasi; (iii) Pasal 75 Ayat (1) dan Ayat (2) UU No. 6 Tahun 2011 yang menjelaskan tentang tindakan 
administratif keimigrasian berupa Deportasi dan pencantuman dalam Daftar Cegah dan Tangkal sebagai wujud pengamanan kedaulatan negara; dan (iv) Pasal 75 dan Bagian Kesatu UU No. 6 Tahun 2011 yang menjelaskan tentang prinsip kebijakan selektif keimigrasian sebagai filter bagi setiap orang yang masuk dan keluar wilayah Indonesia. Berdasarkan prinsip ini, maka hanya orang asing yang dapat memberikan manfaat bagi kesejahteraan rakyat, bangsa, dan negara, serta tidak membahayakan keamanan dan ketertiban, yang dapat masuk dan keluar wilayah Indonesia. Namun, dalam prakteknya, eksistensi kedaulatan negara dalam perspektif keimigrasian dewasa ini menimbulkan dampak kerawanan yang masif. Hal tersebut dapat dilihat dari beberapa contoh kasus kontemporer berikut ini yang cenderung memperlemah kedaulatan negara. (i) Resistensi Implementasi Kebijakan Bebas Visa. Pasca diberlakukannya Peraturan Presiden Nomor 21 Tahun 2016 tentang Bebas Visa Kunjungan, telah banyak menimbulkan kerawanan politik, hukum, keamanan, dan ancaman bagi kedaulatan negara. Hal tersebut dapat dilihat dari pengaruhnya terhadap tugas dan fungsi keimigrasian pada sektor pelayanan, penegakan hukum, pengamanan negara, dan fasilitator pembangunan kesejahteraan masyarakat; (ii) Eksistensi Pengungsi dan Pencari Suaka. Kedatangan para imigran ilegal ke wilayah Indonesia ini jumlahnya terus meningkat, sehingga mulai menimbulkan kekhawatiran dan ketidaknyamanan serta berpeluang menimbulkan gangguan sosial, kemanan politik, bahkan ketertiban di masyarakat.; dan (iii) Eksodus Tenaga Kerja Asing Tiongkok. Keberadaan tenaga kerja Tiongkok ibarat dua sisi mata uang, yang (mungkin) dapat mensejahterakan masyarakat, tapi juga mengganggu keamanan negara. Tidak hanya itu, dalamjangka panjang dapat memberikan pengaruh negatif terhadap perkembangan ideologi, sosial, politik, dan mengancam kedaulatan negara.

\section{SARAN}

Dalam menyikapi permasalahan demikian, maka langkah konkrit yang perlu dilakukan adalah dengan: (i) mengkaji ulang kebijakan Bebas Visa Kunjungan bagi 169 negara dan kebijakan di sektor ketenagakerjaan khususnya yang melibatkan tenaga kerja asing, yang praktiknya malah menimbulkan kerawanan dari aspek kedaulatan negara; (ii) menerapkan prinsip selektif keimigrasian secara ketat terhadap orang asing yang hanya menjadikan Indonesia sebagai negara transit/tujuan bagi orang asing yang mengaku sebagai pencari suaka atau pengungsi; (iii) meningkatkan kualitas dan kuantitas tindakan administratif keimigrasian berupa deportasi dan pencantuman dalam daftar cegah dan tangkal sebagai wujud aksi preventif bagi orang asing yang masuk Indonesia; (iv) melakukan penguatan fungsi penegakan hukum, khususnya penyidikan tindak pidana keimigrasian guna memberikan efek jera bagi setiap orang asing atau pihak yang terlibat melanggar ketentuan keimigrasian; dan (v) meningkatkan koordinasi lintas instansi guna meningkatkan pengawasan terhadap orang asing melalui Tim Pengawasan Orang Asing (Tim Pora) dengan melibatkan TNI, Polri, Kejaksaan, Kementerian Tenaga Kerja dan Transmigrasi, serta lembaga lainnya. 


\section{DAFTAR KEPUSTAKAAN}

\section{Buku-Buku}

Ardhiwisastra,Yudha Bhakti,Imunitas Kedaulatan Negara diforum Pengadilan Asing, Bandung: Alumni,2017.

Chotib, Migrasi: Kajian Kependudukan dan Ketenagakerjaan, Program Pascasarjana Universitas Indonesia, 2013.

Fahroy, Caesar Ali dan M. Alvi Syahrin, "Antara Batas Imajiner dan Kedaulatan Negara", Imigrasi di Batas Imajiner, Jakarta: Kantor Imigrasi Kelas I Khusus Soekarno Hatta, 2016.

Friedman, W,Legal Theory, Fourth Edition, Stevens \& Sons Limited, London,2016.

Indra, Muhammad,Perspektif Penegakan Hukum dalam Hukum Keimigrasian Indonesia, Jakarta: Direktorat Jenderal Imigrasi,2015.

Kusumaatmadja, Mochtar dan Etty R. Agoes,Pengantar Hukum Internasional, Bandung: Alumni. 2013.

Macedo, Stephen (ed),Universal Jurisdiction National Courts and the Prosecution of Serious Crimes Under International Law, University Of Pennsylvania Press, Philladelphia, 2014.

Marzuki, Peter Mahmud,Penelitian Hukum, Jakarta:KencanaPrenada Media Group,2015.

Nasution, M. Arif,Globalisasi dan Migrasi Antar Negara,Bandung: Penerbit Alumni, 2016.

Oscar, Schahter,Internasional Law in Theory and Practice, Martinus Nijhoff Publisher,2013.

Parthiana, Wayan,Beberapa Masalah dalam Hukum Internasional dan Hukum Nasional Indonesia, Jakarta, 2016.

Starke, JG, Introduction to International Law, Butterworths, 2013.

Santoso, M. Iman,Perspektif Imigrasi dalam Migrasi Manusia, Bandung: Pustaka Reka Cipta, 2014.

Santoso,M. Iman,Prespektif Imigrasi Dalam United Nation Convention Against Transnational Organized Crime, Cet.1, Jakarta: Perum Percetakan Negara RI, 2017.
Winer, Myron, Security, Stabillity and International Migration, Centre For International Studies Massachusetts Institute of Technology, Cambridge. Massachusetts,2015.

\section{Karya dan Jurnal Ilmiah}

Berry, J.W. Immigration, Acculturation, and Adaptation. Applied Psychology, 46(1), pp.5-34. 2017.

Bond, E.W. and Chen, T.J. The Welfare Effects of Illegal Immigration. Journal of International Economics, 23(3-4), pp.315-328. 2017.

Ethier, W.J. Illegal immigration: The hostcountry problem. The American economic review, 76(1), pp.56-71. 2016.

Fernando, S. Politik Hukum Pemerintah (Direktorat Jenderal Imigrasi) Dalam Menanggulangi Masalah Penyelundupan Manusia. Jurnal Mahasiswa Fakultas Hukum, 1(1). 2014.

Syahrin, M.A., 2017. The Implementation of NonRefoulement Principle to the Asylum Seekers and Refugees in Indonesia. Sriwijaya Law Review, 1(2), pp.168-178.

\section{Majalah dan Lainnya}

Athira, M,Pemberlakuan Bebas Visa Kunjungan dan Kaitanya dengan Keberadaan Tenaga Kerja Asing Ilegal Asal Tiongkok yang Berpotensi Mengancam Kedaulatan NKRI,Skripsi,Fakultas Hukum Universitas Hasanuddin, Makassar,2017.

Patrnogic, Jovan, "Introduction to International Refugee Law" (makalah yang dibawakan pada Refugee Law Courses, the International Institute of Humanitarian Law, San Remo, Italy, September 2016).

Laporan Kegiatan Rapat Pembahasan NegaraNegara Bebas Visa Kunjungan Dalam Rangka Wisata di Gedung BPPT 1 tanggal 21 Desember 2015.

Syahrin, M. Alvi,Imigran Ilegal, Migrasi atau Ekspansi?,Majalah Check Point,Edisi 3 Oktober 2015, Jakarta: Akademi Imigrasi.

Syahrin, M. Alvi,Penyadapan oleh Australia, Sebaiknya Imigrasi Bersikap,Majalah Bhumi Pura. Januari-Februari 2014, Jakarta: Direktorat Jenderal Imigasi. 


\section{TUUTe Akreditasi LIPI: No:740/AU/P2MI-LIPI/04/2016}

Syahrin, M. Alvi,Eksodus Warga Negara Tiongkok: Antara Kebijakan dan Penyelundupan,Majalah Check Point,Edisi 5 November 2016, Jakarta: Akademi Imigrasi.

Syahrin, M. Alvi,Hak Asasi Bermigrasi,Majalah Bhumi Pura, November 2015, Jakarta: Direktorat Jenderal Imigrasi.

Tinggartomanu, R.Pengawasan dan Intelijen Keimigrasian, Bahan Kuliah disampaikan pada perkuliahan Pendidikan Pejabat Imigrasi (DIKPIM), pada hari Rabu (17 Juni 2015) di Kampus Akademi Imigrasi, Tangerang, 2015.

\section{Peraturan}

Undang-Undang Dasar Negara Republik Indonesia Tahun 1945 (Amandemen)

Indonesia. Undang-Undang tentang Keimigrasian. UU No. 6 Tahun 2011. LN Tahun 2011 Nomor 52.

Peaturan Presiden Nomor 21 Tahun 2016 tentang Bebas Visa Kunjungan.

Peraturan Presiden Nomor 125 Tahun 2016 tentang Penanganan Pengungsi dari Luar Negeri.

Peraturan Menteri Tenaga Kerja dan Transmigrasi Nomor 16 Tahun 2015 tentang Tata Cara Penggunaan Tenaga Kerja Asing.

Keputusan Menteri Tenaga Kerja dan Transmigrasi Nomor 15 Tahun 2015 tentang Jabatan yang Dapat Diduduki oleh Tenaga Kerja Asing pada Kategori Industri Pengolahan, Sub Golongan Industri Alas Kaki.

Piagam Perserikatan Bangsa-Bangsa(Charter of the United Nations).

Konvensi Genewa Tahun 1951 tentang Status Pengungsi (The 1951 Convention Relating the Status of Refugees).

Konvensi Montevideo Tahun 1933 tentang Hak dan Kewajiban Negara (Montevideo Convention the Rights and Duties of State). 
(7) JPe Akreditasi LIPI: No:740/AU/P2MI-LIPI/04/2016

HALAMAN KOSONG 